\title{
PERANCANGAN E-LEARNING DENGAN PENDEKATAN ADDIE MODEL (KASUS : MATA PELAJARAN BAHASA INGGRIS - SD IPEKA TOMANG)
}

\author{
Siswono; Yurika Liona \\ Jurusan Sistem Informasi, Fakultas Ilmu Komputer, Bina Nusantara University \\ Jln. K.H. Syahdan No. 9, Palmerah, Jakarta Barat 11480 \\ siswono@binus.edu
}

\begin{abstract}
Problem faced by SD IPEKA Tomang is not reaching its predicted target in English subject. This is caused by less understanding among students in important parts of English which reflected in making sentences or writing essays. Teachers have difficulty in explaining about grammar usage to students, which is the basic knowledge in making sentences. In order to avoid this problem, SD IPEKA Tomang is adding or replacing the teaching media into a computer media. In doing this analysis and designing of e-learning is using ADDIE Model approach. This research is done through stages of analysis, design, and development. Analysis stage uses Gap Analysis approach to understand the needs of e-learning.
\end{abstract}

Keywords: e-learning, ADDIE model

\begin{abstract}
ABSTRAK
Masalah yang dihadapi SD IPEKA Tomang saat ini adalah target yang diharapkan dalam mata pelajaran Bahasa Inggris tidak terpenuhi. Hal ini disebabkan karena siswa kurang memahami bagian-bagian penting dari Bahasa Inggris yang tercermin dalam pembuatan kalimat atau mengarang. Guru kesulitan dalam menjelaskan tentang penggunaan grammar kepada siswa yang menjadi dasar dalam pembuatan kalimat. Untuk mengatasi permasalahan yang terjadi di SD IPEKA Tomang dengan menambahkan atau menggantikan media pengantara yang ada, yaitu menggunakan media komputer. Dalam melakukan analisis dan perancangan elearning menggunakan pendekatan ADDIE Model. Dalam penelitian ini baru dilaksanakan pada tahap Analysis, Design dan Development. Tahap Analysis menggunakan pendekatan Gap Analysis untuk memahami kebutuhan akan e-learning.
\end{abstract}

Kata kunci: e-learning, ADDIE Model 


\section{PENDAHULUAN}

Perkembangan teknologi khususnya internet sudah berkembang sangat baik. Internet saat ini telah digunakan dalam berbagai bidang usaha termasuk di dalamnya adalah dunia pendidikan. Hal ini dibuktikan dengan banyak sekolah di Pulau Jawa, termasuk Jakarta, yang menggunakan sistem online dalam proses penerimaan siswa baru.

Tuntutan globalisasi pendidikan membuat bahasa asing lebih diperhatikan dan ditekankan oleh masyarakat dewasa ini, pilihan Bahasa Inggris menjadi sebuah bahasa asing umum yang paling banyak digunakan untuk berkomunikasi. Penggunaan bahasa asing di sekolah menjadi pilihan utama bagi orang tua untuk menyekolahkan anak-anak mereka. Sikap seperti ini banyak dilakukan oleh para orang tua agar anak-anak mereka dapat menghadapi tantangan globalisasi. SD IPEKA Tomang melihat bahwa hal tersebut menjadi tantangan bagi sekolah mereka. Oleh sebab itu, SD IPEKA Tomang harus bisa meningkatkan pelayanan peningkatan kepada siswa dengan membuktikan bahwa sekolah biasa yang tanpa ada kerjasama dengan lembaga asing juga dapat memenuhi tuntutan dari orang tua. Dalam kurikulum yang dibuat oleh SD IPEKA Tomang, terdapat pelajaran Bahasa Inggris dimana pada saat pelajaran dimulai siswa/i diharuskan untuk berbicara dalam Bahasa Inggris. Dengan kegiatan seperti ini, maka SD IPEKA Tomang sudah mencoba untuk menjawab tantangan yang ada.

Jika dilihat secara umum, kegiatan pendidikan di sekolah tidak mempunyai masalah. Masalah terlihat ketika siswa mendapatkan nilai yang kurang baik. Tetapi pada proses pembelajaran sehari-hari di dalam kelas, kegiatan-kegiatan yang ada di dalam kelas mengalami banyak kendala. Dalam sebuah pembelajaran bahasa, siswa/i seharusnya mengetahui dengan baik phonology, syntax, semantics, dan pragmatis (Elliot et al, 1999), tetapi banyak siswa/i yang belum bisa menggunakan dengan baik. Hal ini akan menghambat SD IPEKA Tomang untuk mencapai tujuannya. Dengan pendekatan instructional design dalam penelitian ini, maka diharapkan SD IPEKA Tomang dapat membantu untuk menyelesaikan masalah yang terjadi.

Tujuan penelitian ini adalah menghasilkan rancangan e-learning untuk SD IPEKA Tomang dengan subyek penelitian pelajaran bahasa Inggris pada topik phonology (suara), syntax (grammar), semantics (arti kata), pragmatis (penggunaan kata).

\section{METODE}

Penelitian ini menggunakan metodologi dengan pendekatan ADDIE Model Instructional System Design Process yang terdiri dari beberapa tahap yaitu Analysis, Design, Development, Implementation, Evaluation. Pada tahap Analysis akan digunakan Analisis kebutuhan. Tahap Design merupakan sebuah blueprint materi pelajaran Bahasa Inggris (rancangan materi) yang akan digunakan sebagai dasar pengembangan e-learning. Tahap Development berisi rancangan e-learning yang akan dibangun. Dalam penelitian ini Tahap Implementation dan Evaluation belum dapat diberikan.

\section{HASIL DAN PEMBAHASAN}

\section{Studi Pustaka}

Effendi \& Zhuang (2005) mengemukakan bahwa pemakaian kata e-learning ini sering digunakan sebagai semua kegiatan pendidikan yang menggunakan media komputer dan atau internet. 
Jadi, e-learning itu mengacu pada semua kegiatan pelatihan yang menggunakan media elektronik atau teknologi informasi.

Piskurich (2003) mengatakan bahwa setiap orang kurang lebih setuju bahwa e-learning berkaitan dengan teknologi dan banyak yang berpikir bahwa hal tersebut juga berhubungan dengan komputer. Piskurich juga berpendapat bahwa e-learning ini merupakan sebuah disiplin yang masih terus berkembang, sehingga ia menyimpulkan bahwa e-learning adalah pembelajaran yang menggunakan jaringan komputer atau web sebagai mekanisme pengantara, dalam hal ini penggunaan CD-ROM atau satelit juga dapat dipertimbangkan sebagai e-learning.

Ada juga pendapat yang berbeda yang berasal dari Clark \& Mayer (2003), dimana mereka mendefinisikan e-learning sebagai penyampaian instruksi ke sebuah komputer dengan menggunakan CD-ROM, internet, atau intranet dengan fitur-fitur yang termasuk di dalamnya konten/isi yang relevan dengan tujuan pembelajaran, menggunakan metode instruksional seperti contoh dan latihan untuk membantu pembelajaran, menggunakan media element seperti kata-kata atau gambar untuk menyampaikan konten dan metode, serta membangun pengetahuan baru dan skill yang berkaitan dengan goal pembelajaran individual atau meningkatkan kinerja perusahaan.

Gagné et al (2005) menjelaskan bahwa Instructional Systems Design (ISD) adalah sebuah proses pembuatan instructional system, baik secara sistematis dan scientific yang bisa didokumentasikan, memungkinkan dalam aplikasi yang umum dan membawa kepada outcomes yang bisa diramalkan. ISD ini mencakup beberapa fase yaitu analysis, design, development, implementation, dan evaluation serta dikarakteristikan oleh pencapaian konsep sebuah design. ISD ini juga mencakup teori sistem dan metodologi problem solving, dimana menerangkan sebuah paradigma dasar untuk menjelaskan dan menghasilkan lingkungan pembelajaran untuk pelatihan dan edukasi.

Dalam pengembangannya, sebuah instructional system mencakup kategori pembelajaran yang difokuskan, strategi penyimpanan pembelajaran, metode untuk pengantara pembelajaran, dan prinsip. Sebuah instructional system juga menyediakan sebuah framework untuk proses dalam mengembangkan lingkungan tersebut. Proses dasar dalam sebuah instructional system design adalah pengembangan instructional system dengan menggunakan ADDIE model (analysis, design, development, implementation, evaluation), seperti pada Gambar 1.

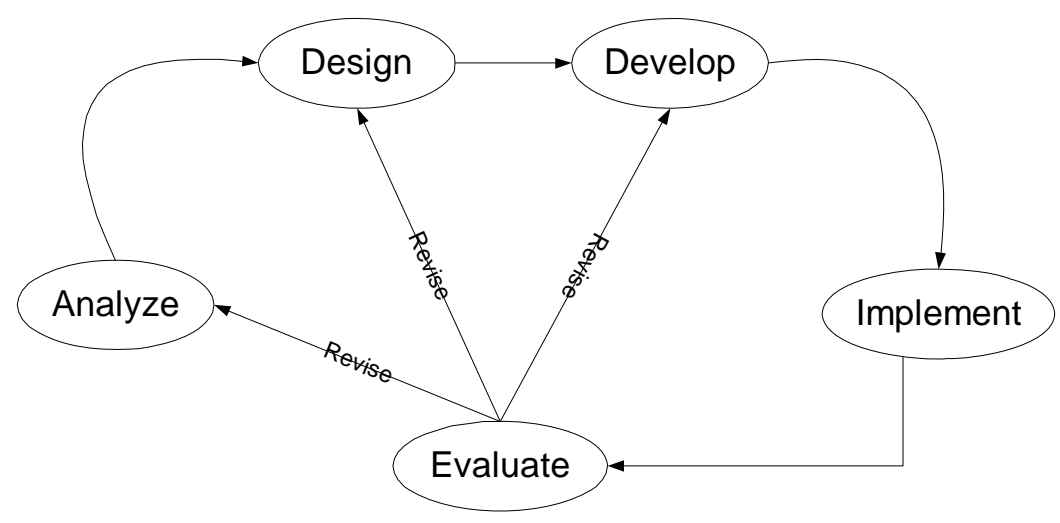

Gambar 1 ADDIE Model

Sumber: Gagné et al. (2005)

\section{Proses Pembelajaran yang ada di SD IPEKA Tomang}

Gambar 2 memperlihatkan proses pembelajaran bahasa Inggris yang terjadi selama ini di dalam kelas antara Siswa dengan Guru. 


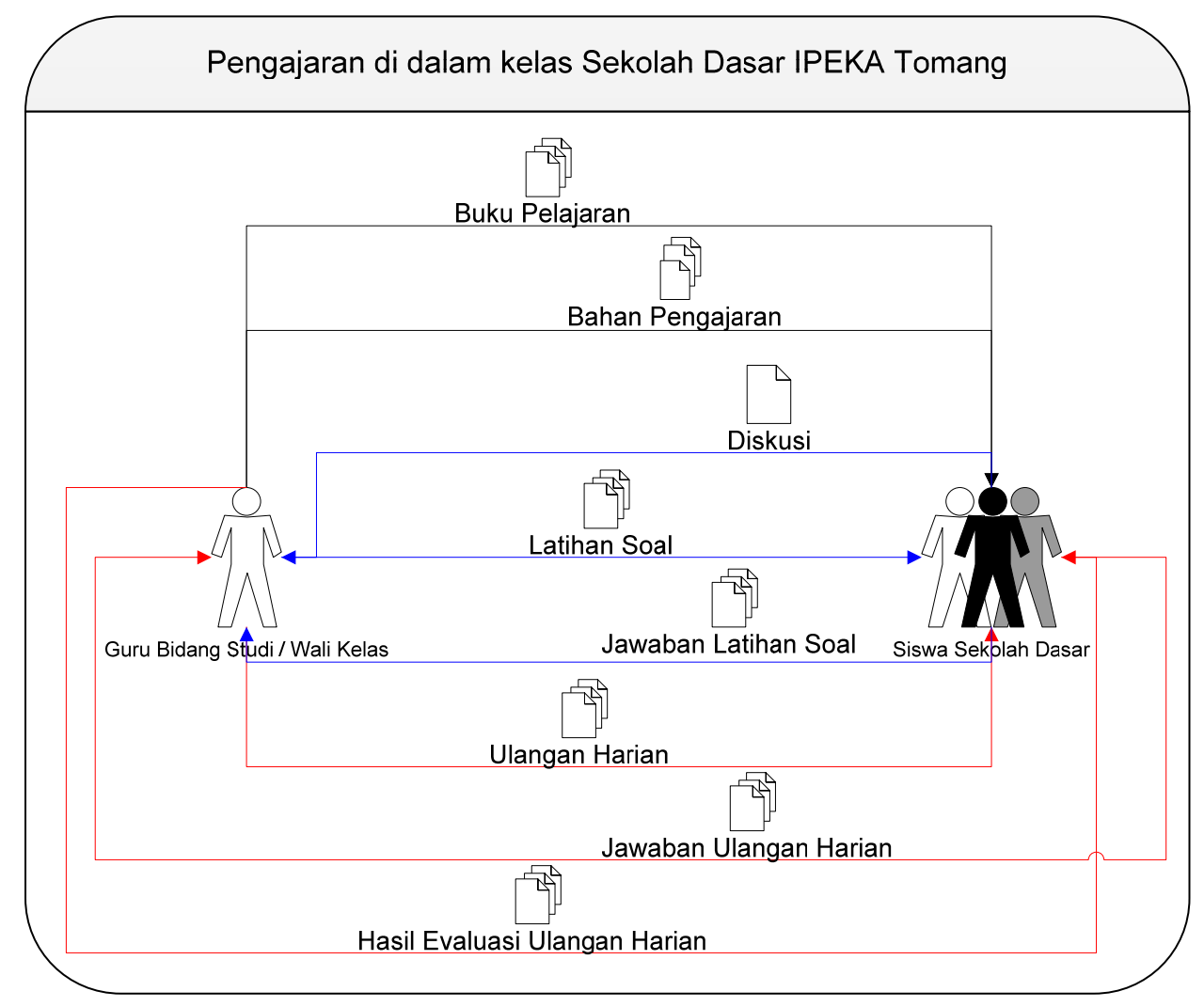

Gambar 2 Proses Pembelajaran Bahasa Inggris di dalam kelas

\section{Analisis Kebutuhan (Gap Analysis)}

Analisis kebutuhan dilakukan dengan memperhatikan beberapa hal penting dimulai dari Tujuan pembelajaran bahasa Inggris yang diterapkan di SD IPEKA Tomang, kinerja yang diinginkan dan kinerja yang sebenarnya terjadi pada saat penelitian ini dilaksanakan. Dari perbedaan pada kinerja tersebut diketahui permasalah yang terjadi. Gambar 3 memperlihatkan lebih jelas akan analisis kebutuhan ini.

\section{Perancangan}

Perancangan yang dilakukan berdasarkan kebutuhan instruksi yang dibutuhkan. Kebutuhan instruksi ini dilihat dari 2 hal yaitu learning outcomes dan external event yang akan dipergunakan. Dari hasil analisa diatas maka learning outcomes yang diperlukan adalah intellectual skill, cognitive strategies, verbal information, dan attitude.

Sementara itu, external event yang dibutuhkan dalam pembelajaran Bahasa Inggris ini adalah: (1) gain attention, menarik perhatian dari siswa untuk memberitahukan kepada siswa tentang pembelajaran hari itu; (2) present learner objectives, setelah pembukaan dari guru diselesaikan, maka guru akan memberikan tujuan pembelajaran materi hari itu. unit 1 akan dipelajari selama 5 kali pertemuan dan setelahnya guru akan memberikan ulangan harian; (3) recall prerequisite knowledge, setiap pengajaran membutuhkan pengetahuan dari pelajaran sebelumnya atau mata pelajaran sebelumnya; (4) present new content, setiap kali pertemuan guru akan mengulang pelajaran terdahulu dan juga menambah pengetahuan yang baru kepada murid dengan menerangkan di depan kelas; (5) 
provide learner guidance, pengajar memberikan catatan atau memberikan contoh-contoh kalimat yang bisa dibuat oleh siswa; (6) provide practice, latihan soal sangat diperlukan bagi siswa untuk melatih kemampuan siswa. bentuk latihan yang diberikan oleh guru ada tiga tipe yaitu pekerjaan sekolah, pekerjaan rumah; (7) provide feedback, pengajar mengembalikan hasil dari latihan tersebut baik yang berasal dari homework maupun workbook; (8) assess performance, ulangan harian dan ulangan umum akan menilai kemampuan siswa dalam memahami unit-unit dalam bahasa inggris; (9) enhance retention and transfer, guru akan memberikan latihan soal review setiap sudah membahas dua buah unit. latihan soal ini akan melatih kemampuan siswa untuk bisa meningkatkan kemampuan siswa.

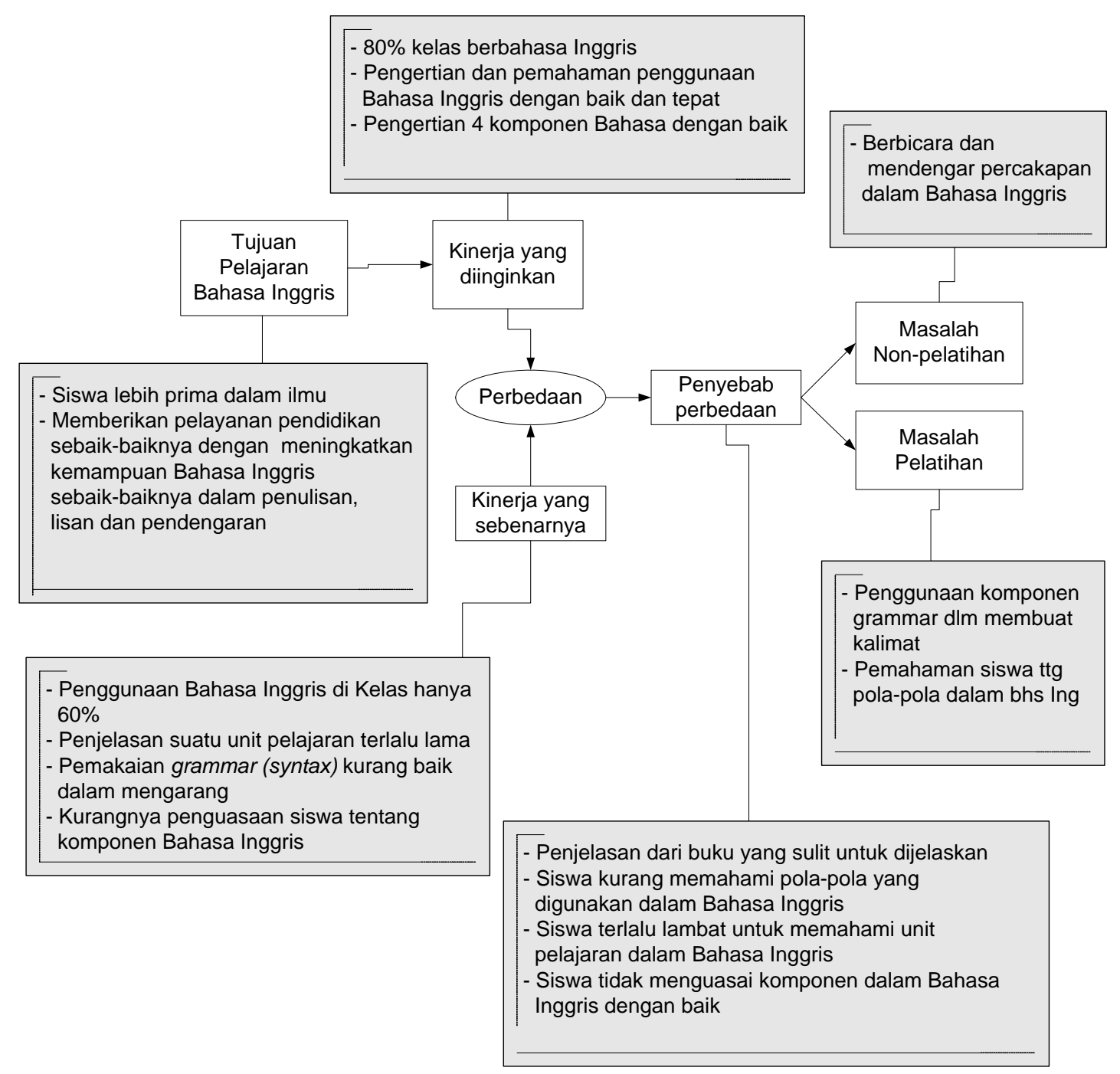

Gambar 3 Analisis Kebutuhan

Dengan hasil penelitian seperti itu metode pembelajaran baru yang dapat diterapkan di SD IPEKA Tomang adalah dengan menggunakan metode computer-based training secara online atau stand-alone. Saat ini, SD IPEKA Tomang sudah memasang jaringan LAN dan guru akan lebih mudah memantau perkembangan siswa jika secara online. Tipe media yang digunakan untuk sistem ini adalah multimedia dan strategi yang dapat digunakan digunakan adalah collaborative learning, lecture/tutorial dan practice. Sistem yang yang akan dibangun adalah sebagai berikut : 


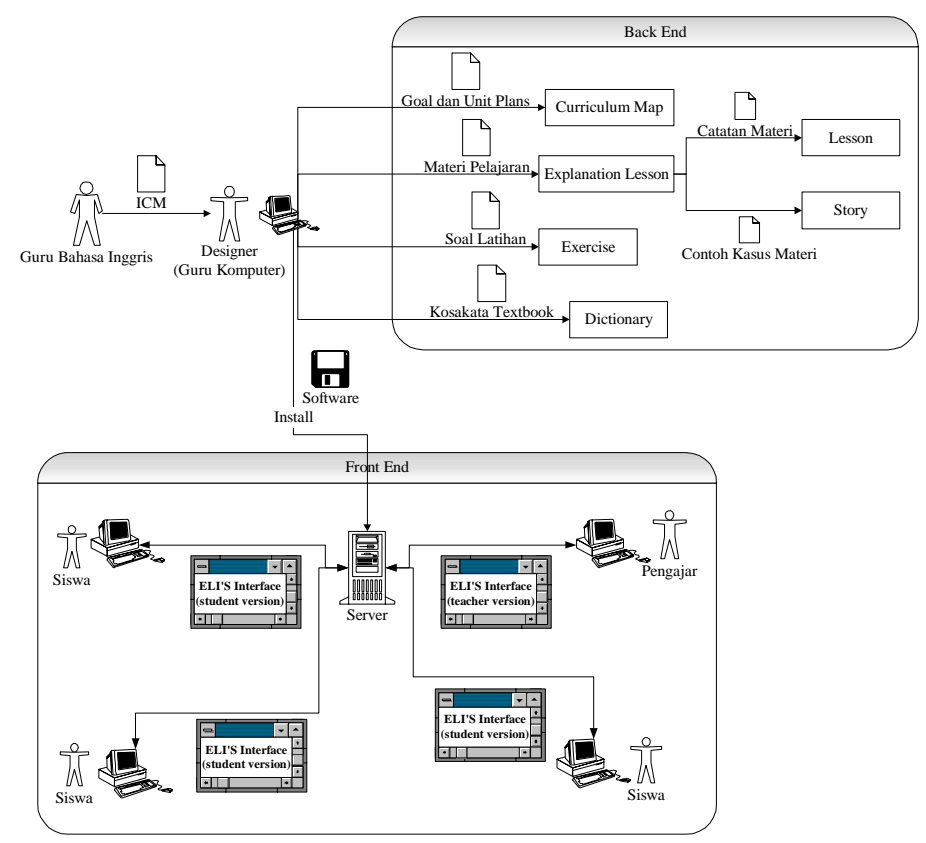

Gambar 4 Rancangan Sistem yang Diusulkan

Pada awal tahun ajaran baru, Rencana Ajaran yang telah disetujui oleh Kepala Sekolah diserahkan kepada designer untuk dimasukkan ke dalam sistem yang telah dibuat. Dalam Rencana Ajaran atau yang disebut Instructional Curiculum Maps tersebut, designer dapat memisahkan bagian mana yang akan terdapat di fitur di sistem e-learning ini. Fitur-fitur yang mendukung pengajaran adalah (1) fitur learning plan, fitur ini memberikan penjelasan kepada siswa tentang pelajaran bahasa inggris secara umum dan pelajaran-pelajaran yang akan dipelajari selama waktu satu tahun; (2) fitur lesson, fitur ini akan memberikan penjelasan materi kepada siswa. di fitur ini siswa dapat melihat catatan yang diberikan dan dapat mereview catatan terdahulu; (3) fitur story, fitur ini berupa alat peraga atau contoh kasus dimana fitur ini menyediakan animasi pendek sesuai dengan tema-tema yang diajarkan oleh pengajar; (4) fitur exercise, fitur ini berisi latihan-latihan yang biasa diberikan dalam pengajaran konvensional; (5) fitur dictionary, fitur ini merupakan sebuah fitur yang akan memberikan penjelasan tentang arti sebuah kata dalam bahasa inggris. fitur ini bisa dua arah, baik dari bahasa inggris ke bahasa indonesia dan dari bahasa indonesia ke bahasa inggris. Rancangan Layar yang akan dibuat dalam sistem ini adalah sebagai berikut (Gambar 5-11):

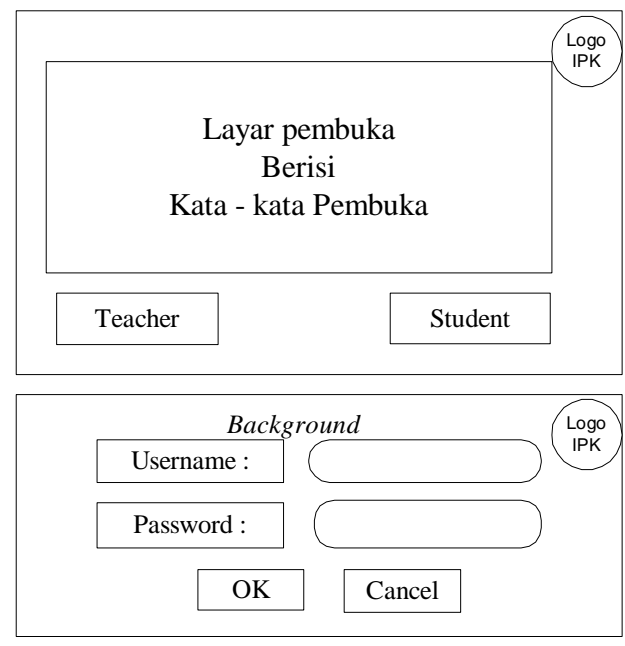

Gambar 5 Rancangan Layar Halaman LogIn 


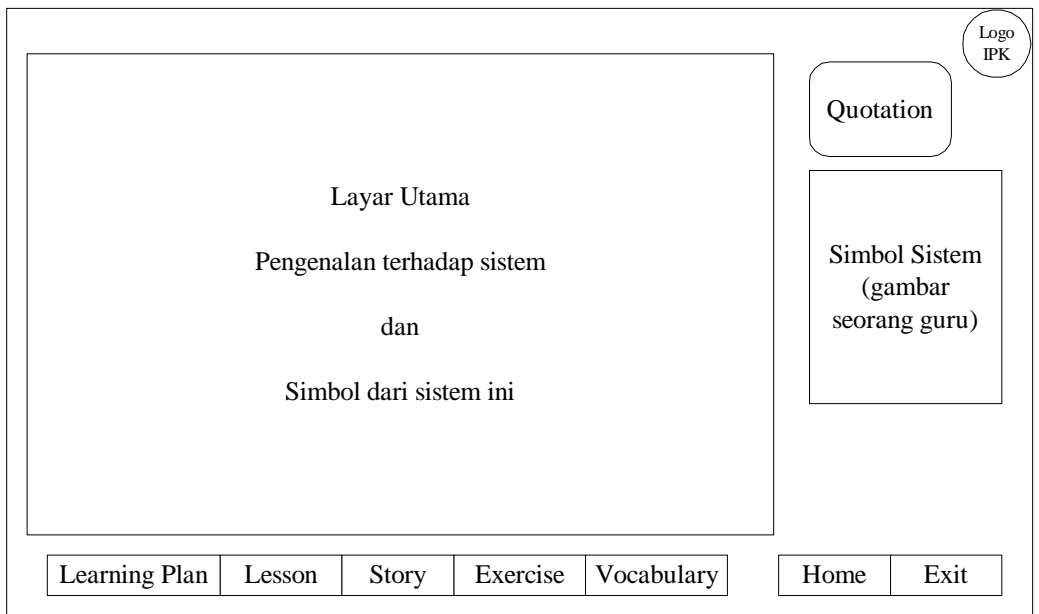

Gambar 6 Rancangan layar halaman utama

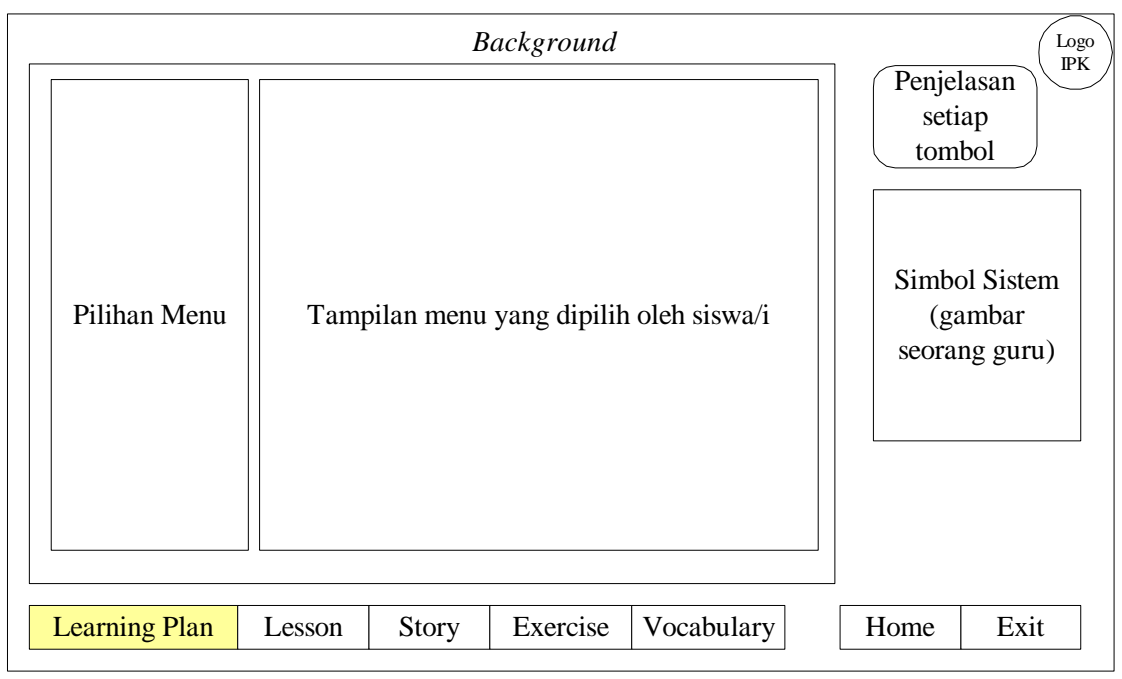

Gambar 7 Rancangan layar halaman learning plan

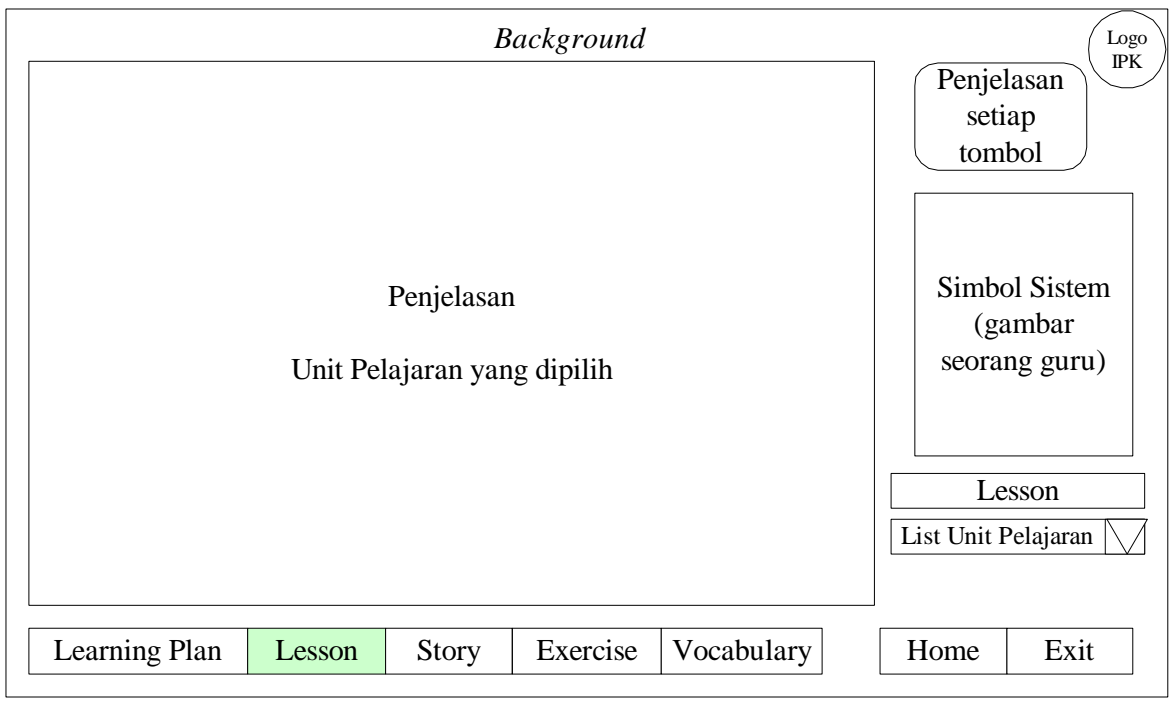

Gambar 8 Rancangan layar halaman lesson/story 


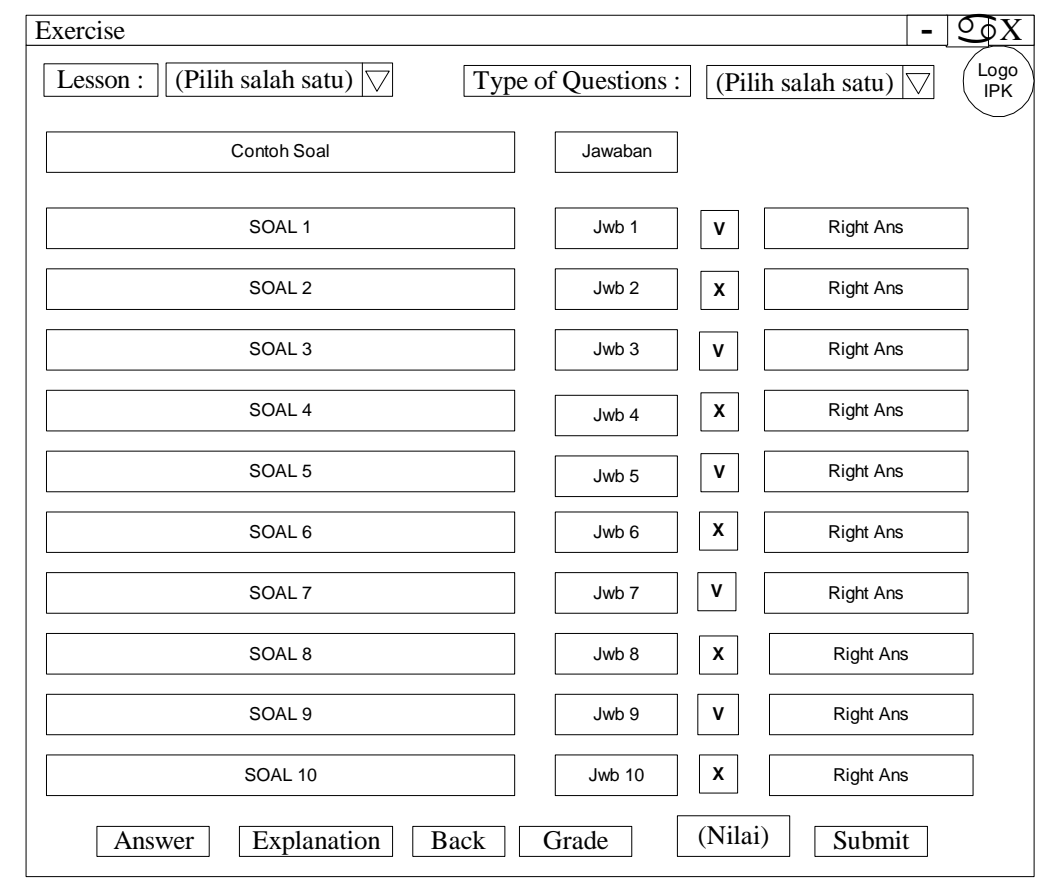

Gambar 10 Rancangan layar halaman exercise (bg. Isian)

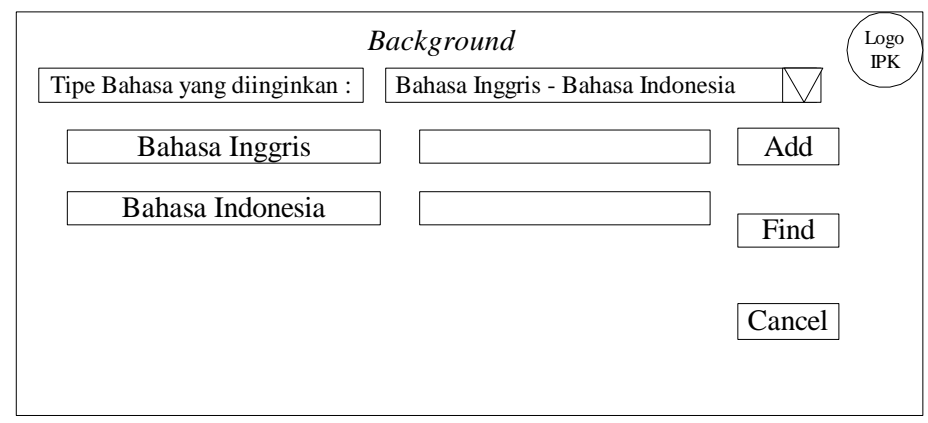

Gambar 11 Rancangan Layar Kamus Bahasa Inggris ke Bahasa Indonesia

\section{SIMPULAN}

Berdasarkan hasil dan pembahasan perancangan e-learning di atas dapat ditarik kesimpulan bahwa (1) masalah yang timbul dari siswa SD IPEKA Tomang adalah siswa mengalami kesulitan dalam menguasai bagian mengarang dalam Bahasa Inggris. Mengarang ini merupakan bagian Bahasa Inggris dimana komponen syntax (grammar) dan semantics (arti kata) mempunyai penilaian yang paling penting; (2) pembelajaran secara elektronik ini berusaha menjembatani antara buku bacaan, penerangan yang diberikan oleh guru dan pemahaman siswa. Aplikasi yang akan diterapkan ini akan membuat guru lebih mudah untuk menerangkan dengan bantuan cerita-cerita dengan menggunakan grammar tertentu dan akan membuat siswa lebih tertarik mempelajari serta siswa akan mudah untuk memahaminya; (3) pembelajaran secara elektronik (e-Learning) akan merubah proses pembelajaran yang terdapat di SD IPEKA Tomang dari pembelajaran dengan menggunakan whiteboard menjadi pembelajaran media komputer sebagai pengantara proses pembelajaran yang terjadi di dalam kelas. 
Untuk melengkapi penelitian ini diharapkan dapat memberikan usulan implementasi dan evaluasi yang dapat dipergunakan oleh SD IPEKA Tomang sehingga dapat dipergunakan sebagai panduan bagi sekolah untuk menerapkan aplikasi ini dan bagaimana cara untuk mengevaluasinya (tahap implementation dan evaluation).

\section{DAFTAR PUSTAKA}

Clark, R. C., \& Mayer, R. E. (2003). E-learning and the Science of Instruction. San Francisco: Pfeiffer.

Effendi, E., \& Zhuang, H. (2005). E-learning: Konsep dan Aplikasi (1st ed.). Yogyakarta: C.V. Andi Offset.

Elliot, S. N., Kratochwill, T. R., Littlefield, J., \& Travers, J. F. (1999). Educational Psychology: Effective Teaching, Effective Learning (2nd ed.). Madison: Brown and Benchmark.

Gagne, R. M., Wager, W. M., Golas, K. C., \& Keller, J. M. (2005). Principles of Instructional Design (5th ed.). Belmont, Canada: Thomson Wadworth.

Piskurich, G. M. (2003). The AMA Handbook of E-Learning: Effective Design, Implementation, and Technology Solutions. New York: AMACOM. 